\title{
Relationship of Training and Education with Employee Performance in Financial Institutions
}

\author{
Nabila Khan ${ }^{1}$, Naveed Ahmad ${ }^{1, *}$, Nadeem Iqbal ${ }^{2}$, Najeeb Haider ${ }^{3}$ \\ ${ }^{1}$ Faculty of Management Science, Indus International Institute, DG Khan, Pakistan \\ ${ }^{2}$ Faculty of Management Science, Ghazi University, DG Khan, Pakistan \\ ${ }^{3}$ Faculty of Statistics, Ghazi University, DG Khan, Pakistan \\ *E-mail address: naveeddgk2010@gmail.com
}

\begin{abstract}
The aim of this study is to investigate the training that has positive impact on employees' performance and productivity. This paper is quantitative in nature. Data for the paper have been collected through primary source by questionnaires surveys. The data have been checked through statistical software to find the influence and relationship of training on performance of employees. There are two variable Training (Independent) and Employees' performance (Dependent). Seven conventional banks limited are selected for the study. It is concluded that training has strong positive impact on employee performance whereas education is negatively correlated with performance in the financial institution of southern Punjab. The research paper suggest that professional training is essential element of human capital development which leads to higher productivity and performance.
\end{abstract}

Keywords: Training; employee performance; reward; banks; education

\section{INTRODUCTION}

In the recent years, Banking sector has been adopted wide-ranging organizational and structural changes worldwide In this sector drastic change has been occurred by major factors such as deregulation of familial banking system and movement of financial markets and services in different countries. Banks are the vital institution in any society as they significantly contribute to the development of an economy through facilitation of Business. The far-reaching competition and dynamic business atmospheres have developed and encouraged demanding customers for better product and services. So it has also increased more demand for employees to meet the requirements of this competitive Era.

Organizations enhance the skills, abilities and quality of new and existing employees by a methodical way. Training is system of planned and organized activities of continuous learning that improve as well as individual, group and firms (Goldstein\& Ford, 2010) in Khawaja \& Nadeem (2012).Basically it is the sequence of activities followed by organization to acquiring knowledge or capabilities and skills for grooming and development purposes. So it analyzed that training is the major contributor to the performance and betterment of human capital. According to Manju \& Suresh (2011), training try to work as an intrusion that increase the quality of organization's products and services. Competency and technical skills can be 
improved by training of employees and organization will be a part of extensive competition in the business environment.

In Global market, some sources considered more vital to competitive advantage like as capabilities, skills for competent workforce. (McKinsey, 2006). If organization try to get and develop the standard skills, capabilities of employees they must require the effective training then employees perform in good way and also influence the commitment level. (Meyer and Allen, 1991). Mostly organizations facilitate employees by training basically they want to enhance their employee potential to perform assigned tasks as standard. Firms plan for long term to invest in effective training programs that make them able to survive with the uncertain challenges that may face in future, through this they get the highest level of commitment and motivation. Organizations are more interested by offering training programs, putting employee's best efforts for the accomplishment of organizational tasks.

Creation is mixture of completely deliberate items or things and everything has its own vitality and continuity to perform its functions by strong commitment and assimilation in all of them. And they know about their boundaries so in this way they can manage everything in a systematic way. Like as firms is mix of multiple departments and each has included number of people with different thoughts, attitude, values, behavior, culture and work experience for accomplishing some specific sort of goals.

In any business setup, no one is fully specialized and blessed with technical expertise or hold the capability of managing each assigned tasks. Training have become influencing factor regarding employees abilities, capabilities and behavior. Employees work in organization interdependent way in any form either at individual level or in group and team. They need a healthy support of each other during work for accomplishing assigned tasks.

The Basically research aim is to explore the impact of training on employee productivity and performance. Training proves more essential in the work association. If employees don't emphasize on training then they cannot get firm grip upon their duties and roles. Through training workers learn advanced information, techniques and tactics, or professional developments and a lot of opportunities. Effective training programs proves helpful in developing more proactive erudition atmosphere for employees to get prepared them for dealing at the spot uncertain environmental factors and challenges. According to M. Farooq \& Aslam M K (2011) management always struggle for developing best and potential work atmosphere in organization, so for that they must enhance the capability of their employees, then management adopt training efforts to increase and enhance the abilities of workers which is more supportive for accomplishing the organizational tasks. When management putt this effort for organizational tasks it just not good for employees grooming of abilities but also develop the best repute of organization globally (Jia-Fang, 2011).

In this competitive era, to achieve the competitive edge employees must have to get awareness of new techniques and advancement that have come in the field of technology by effective training. (Robert, 2006). There are many functions and role which is performed by human resource management ultimately the basic role is determining and grooming the employee's abilities through proper training. Banking system involve in the service industry where service is offered and delivered by human resource personnel and at the spot used by the customers. As known that competent personnel consider an asset for organizational productivity and development. As banking system require compatible employees to offer their service packages to clients in the desired and standard way to retain their customer and maintain profitability. Development known as competency and aptitude enhancing factor for workforce. 
Through this, organization can get the desired productivity (Elena P. 2013). Management much satisfied with trained workforce and by their work as they become contributor for maximization of organizational profit. (Champathes, 20012).

Organizations want to achieve competitive edge by considered vitality of training to enhance workers productivity and performance. Prior research work showed that positive relationship between training and performance of employees as well as organizational productivity. Other side the past research concluded that organization achieve highest return by investing on training and development plans. Effective training programs proved beneficial for workers retention for long term with organization. (Olarelli \& Montei, 1996; Becker, 1999)

In spite of a lot of research work to explore the relationship regarding training and performance of personnel so that possess some fissure, basic concern of the research is to find this fissure through exploring this occurrence with help of related studies and also recommend some guidance and directions to the organization by developing the potential of employees by offering some sort of training and development programs.

\section{LITERATURE REVIEW}

Iqbal et al.( 2014) described that training has the positive impact on employees performance in the context of "Telecommunication Sector of D. G. Khan" Pakistan. They pointed out the significance of training for human development. In this research paper, they identified that everybody currently acknowledged that training is more important for the achievement and progress of the establishments. Workers consider essential and exclusive source to all association for their contribution. There are the significant variations now in relations to the vitality of the worker due to human capital growth and development. Training is, thus essential to improve the awareness, abilities and assertiveness of the workers. It is concluded from the paper that training will also create opportunity for workers to obtain additional information based on the training.

Nda \& et al, (2013) pointed out training has become necessity in the competitive era. Human resources distinguishes a competitive organization from others. Organization want to get both short and long term advantage by putting their investment in proper training programs. Workers has become unconditional, developing the desire to learn continuously and bracing the abilities and advance information by the competitive environment due to rapid change in technology and structure of organization. So organization understand the crucial requirement for managing proper investment on training to get the maximum return by enhancing employee performance. In extensive competition human capital consider more significant asset for all firms. So training plays an important function to the progress and performance of employees.

Employees have stakes regarding accomplishment of organizational goals due to that positivity with their profession they consider stakeholders which is directly or indirectly influenced by the organization interests. Organizations that known as achiever in the dynamic market they adopt team oriented environment where management understand their subordinates as partner and team members. They participate in all work activities and learn new things continuously. Management involve their employees while making wide decisions and develop the capability to solve issues faced by organizations. When management have concern with their opinion then it will develop the high trustworthiness devotion with organization. In competitive worldwide organization try to become creative and innovative continuously, follow persistent growth and progress and deal with challenges faced by external environment. Organizations should offer proper and effective training programs by a formalized way just to 
enhance the aptitude and caliber of their employees which prove helpful for achieving organizational goals.

According to Elenaga ,et al (2013) employees are vital asset for any organization. they put their efforts while achieving assigned tasks and getting maximum productivity. Higher authorities understand the significance of effective training programs and prefer to invest into these improving employee performance activities.

Rohan \& Madhumita (2012) pointed out the idea to arrange the effective training session for developing power of decision making, team oriented work environment and must have compatibility to solve the dilemma. after getting awareness through training they try their best to attain the expected level of growth and productivity of organization. Training influence workforce's attitude and abilities regarding work that concluded into a constructive change in productivity of organization and performance of employees. If an organization want to achieve its primary goal, it must adopt the training as systematic way to encourage and enhance loyalty in human capital.

Singh \& Mohanty, (2012) concluded the influence of training on employee performance. That provided an assessment of the present confirmation for such positive influence and also gives some directions for future research. An evaluation of past studies where want to investigate the influence of Human resource practices at individual level such as skills enhancing development programs in banking system. Since getting different sort of analysis of some studies find the diverse results, in some cases showed the positive impact of training on performance of employees. And others studies possess the negativity in relationship and whatsoever.

Zaki et al., (2011) suggested that positive influence of training and development programs on workforce performance and organization productivity. Management assess appropriateness for all business activities and find out some sort of deficiencies occur in performance factors through offering training and development programs and provide some directions to reduce the errors. This research comprises some limitations and conduction of empirical research indicate the direct correlation of training session and employees development and assess the proposition that find in study. Basically this study revealed concise the review of different journalism regarding the effectiveness of training and development on employee performance. So training become the major contributor for improving employee performance and offer some suggestions for next conducting studies to explore this positive influence of training on productivity and progress of organizations.

Even though, Truss conducted broad study in the field of human resource practices. human resource management emphasize on orientation and as well as training session after recruiting the candidates. Basic concern of this research assessed relationship between training and employee performance using Banking sector. If try to get understanding of research findings, some tasks were determined that emphasized the training programs for current faculty in organization, aim of the offering training session, adopted tactics , and at the end view the positive influence of training on employee performance.

Khan, et all ( 2011) suggested that management get the desired results of assigned tasks through effective training and development programs. Research applications revealed that training become major force which support the results organization can increase and maximize the progress and productivity level as well as quality of work done by team members.

In the view of Vallet et all. (2008), organizations adopt proper channel for training session to develop their employees competency to cope up with uncertain environment and make accurate decisions that will facilitate them in dynamic business environment. Training programs proves more essential and sympathetic by organization in multiple methods as they 
play important role for employee development. Sepulveda (2005) suggested that effective training is known as mechanism that primarily influence the completion of firm's plan and objectives. So organization ultimately aim is to get maximum profit and high return by achieving targeted goals through utilizing their efficient workforce. Apt and suitable effective training programs lead to progress of organization and workforce abilities which is the necessity for accomplishment of goals. As employee's motivation increases it proved beneficial for the firm in terms of get maximum return.

In the view of Hanif (2004), workforce are the most self-motivated people for every organizations. They demand more attention from top management. Top management will get earn an advantage of potential working atmosphere with high retention level of employee. Management understand the need of training programs for enabling them to perform their goals according to the organization expected goals. It can be given through multiple ways like as on the instruction and peer's coordination and also Involvement by the employees. Team oriented work must make them able to show active involvement in performing tasks and actively participate on the job. Organization try to achieve competitive edge by making best use of their workforce skills So it views obligatory for organizations to develop plans of training for employees.

\section{METHODOLOGY}

In this paper, the researcher wants to measure the influence of training along with other factors on employee performance in banking sector of DG Khan. Sample size of the study consists of 35 employees from seven banks of Taunsa, DG Khan. The study collected primary data through questionnaire using the Likert Scale. Questionnaire consists of 24 question which leads to different variables for study. Descriptive statistics and regression is used for data analysis.

\begin{tabular}{|c|c|c|c|c|c|c|}
\hline \multicolumn{7}{|c|}{ Coefficients $^{a}$} \\
\hline & \multirow[t]{2}{*}{ Model } & \multicolumn{2}{|c|}{$\begin{array}{c}\text { Unstandardized } \\
\text { Coefficients }\end{array}$} & $\begin{array}{l}\text { Standardized } \\
\text { Coefficients }\end{array}$ & \multirow[t]{2}{*}{$\mathrm{T}$} & \multirow[t]{2}{*}{ Sig. } \\
\hline & & B & Std. Error & Beta & & \\
\hline \multirow{6}{*}{1} & (Constant) & .442 & .497 & & .889 & .381 \\
\hline & REWARD & .251 & .227 & .269 & 1.105 & .278 \\
\hline & TRAINING & .685 & .271 & .595 & 2.523 & .017 \\
\hline & GENDER & .112 & .153 & .076 & .729 & .472 \\
\hline & AGE & .016 & .129 & .013 & .121 & .905 \\
\hline & EDUCATION & -.151 & .154 & -.103 & -.981 & .335 \\
\hline
\end{tabular}

a. Dependent Variable: PERFORMANCE

\section{RESULTS}

The analysis of statistical data shows the positive impact and relationship between training and Employee performance. According to results, R Square $=0.716$ which implies 71 $\%$ variation in performance as explained by Training. The positive influence of training on employee productivity and development effect of training and development and statistically 
significant at $1 \%$ level of significance. The Regression model is established, Training coefficient is 0.694 , this shows that $1 \%$ invest in Training will cause increase in Employee performance on average by $69 \%$ that is twice greater influence than other variable Reward. It concludes that variable Education has frail relationship with the other independent variable that is more cleared by viewing results as (-.151) between training and reward from coefficients. outcome are fragment vary by the general thoughts of the persons about training which is the major contributor for enhancing employee performance than reward and education. Mostly people prefer Education but it can be major factor for getting job assignment but not fully contributing to enhance the performance of Employees.

\section{CONCLUSIONS}

Applying Statistical techniques and interpreting the collected data it is identified the significant strong relation between Training development program and employee performance. Analysis showed that the strong influence of training rather than Education on performance of employees. Training is an important aspect for performance enhancement that maximize the workforce as well as organizational aptitude and proficiency. This contributes to minimize the fissure between what should do and what has done, among expected targets and actual results. performance and productivity can be enhanced by effective training programs, for developing error free workforce presentation in performing tasks, management must adopt training programs. It will improve and enhance their capabilities, experience and expertise and make them more progressive. Organization achievement depend upon skilled and expert workforce so they invest in training programs continuously and get the desired results. That will make sure to deliver proper faculty which are specialized in their field and requirement of desired position. Management must emphasize on continuous erudition, knowledge and advanced information for employee. Thus all team members should have to team up efficiently and conversed the mandatory of progress. Therefore training should be follow up a systematic way where all activities will determine and deliberate in accordance with the demand of competitive era.

\section{References}

[1] Brinkerhoff Robert. O. (2006). Increasing Impacts of Training Investments: An Evaluation Strategy for Building Organizational Learning Capability, Industrial and Commercial Banking. Emerald Group of Publishers, 38(6), 302-307.

[2] Colarelli S. M., Montei M. S., The Journal of Applied Behavioral Science 32(3) (1996) 306-322.

[3] Champathes M. R., Development and Learning in Organizations: An International Journal 20(2) (2006) 17-18.

[4] Elenaga, Imran, European Journal Of Bussiness \& Management Review 5(4) (2013)

[5] Farooq M., Khan M. A. (2011). Impact of Training and Feedback on Employee Performance Goldstein IL,

[6] Ford J.K. (2010). Training in Organizations. BCA; Wadsworth. $4^{\text {th }}$ ed. 
[7] Goldstein I. L., "Training in work organizations. In M. D. Dunnette\& L. M. Hough (Eds.)", Handbook of industrial and organizationalpsychologists Press, Palo Alto CA: Consulting Psychologists Press, 2002, 507-6

[8] Ahmad N., Iqbal N., Haider Z., Hamad N., Arabian Journal of Business and Management Review 2(4) (2014).

[9] Iqbal N., Javaid K., Ahmad N., Ateeq M., Management and Administrative Sciences Review 2(4) (2013) 379-390.

[10] Javaid K., Ahmad N., Iqbal N., International Letters of Social and Humanistic Sciences 6 (2014) 60-73.

[11] Hanif F. (2013). Impact of Training on Employee's Development and Performance in Hotel Industry of Lahore, Pakistan. Journal of Business Studies Quarterly, 4(4). Far East Journal of Psychology and Business, 5(2), 23-33.

[12] Khan F., Yusoff R. M., Khan A. (2014). Effect of Human Resource Practices on Job satisfaction in Pakistan. Sains Humanika, 1(1).

[13] Khawaja \& Nadeem, European Journal of Business and Management 5(2) (2013).

[14] McKinsey Quarterly, Canadian Journal of Administrative Sciences 17(4) (2005) 319-331.

[15] Nda M. M., Fard R. Y., The Impact Of Employee Training And Development On Employee Productivity.

[16] Rohan S., Madhumita M., Interscience Management Review 2(2) (2012).

[17] Rosti Jr, R. T., Shipper F., Journal of Managerial Psychology 13(1/2) (1998) 77-89.

[18] Sepúlveda F., Economic Papers 62(3) (2010) 504-528.

[19] Singh A. P., Assessment of Organizational Strategies to Improve the Competencies of Employees

[20] Singh N., Singh B. N., Recent Trends in Training and Developments in Indian Health-Care Sectors in the Changed Economic Scene

[21] Tyson S., Fell A. (1986). Evaluating the personnel function. Hutchinson Radius.

[22] Truss K., Soane E., Edwards C. Y. L., Wisdom K., Croll A., Burnett J. (2006). Working life: employee attitudes and engagement 2006. Chartered Institute of Personnel and Development.

[23] Wright P., Geroy D. G., International Journal of Human Resource Management 12(4) (2001) 586-600. 